\title{
Total and Polyaromatic Hydrocarbons in Water, Sediment, Fin and Shellfishes from Badagry Creek and Ologe Lagoon, Lagos, Nigeria
}

\author{
${ }^{1}$ ADERINOLA, OJ; ${ }^{2 *}$ MEKULEYI, GO; ${ }^{2}$ WHENU, OO
}

\author{
${ }^{I}$ Department of Zoology and Environmental Biology, ${ }^{2}$ Department of Fisheries, Lagos State University, Nigeria \\ *Correspondence:gabrielmekuleyi@gmail.com; Toyinakinmoorin@gmail.com
}

\begin{abstract}
The concentrations of eleven (11) polyaromatic hydrocarbons (PAHs) and total hydrocarbons (THC) were investigated in the water, sediment, Chrysichthys nigrodigitatus and Macrobrachium macrobrachion from Badagry Creek and Ologe Lagoon in Lagos, Nigeria using EPA and Gas Chromatography (GC) methods. All the samples(except water measured in $\mathrm{mg} / \mathrm{l}$ ) were measured in $\mu \mathrm{g} / \mathrm{g}$. PAHs were not significantly different( $\mathrm{p}>0.05$ )across the two stations and were within WHO recommended limit.The highest concentration of THC from Badagry Creek was recorded in $M$. macrobrachion $(219.565 \pm 171.891 \mu \mathrm{g} / \mathrm{g})$ and this value exceeded WHO recommended limit. Similarly, the highest THC $(211.565 \pm 127.923 \mu \mathrm{g} / \mathrm{g})$ recorded in M .macrobrachion at Ologe Lagoon was above WHO limit. The study has shown that the polyaromatic hydrocarbons were below the risk level, which indicated no risk status from the consumption of the fish species studied. However, $C$. nigrodigitatus and M. macrobrachion studied from these water bodies are highly contaminated with THC. Therefore, persistent monitoring and strict adherence to responsible waste discharge should be upheld by all industries near these waters in order to avoid deleterious effects on the biota as well as ensuring safety of the consumers.
\end{abstract}

\section{DOI: $\underline{\text { https://dx.doi.org/10.4314/jasem.v22i5.10 }}$}

Copyright: Copyright (ㅇ 2018 Aderinola et al. This is an open access article distributed under the Creative Commons Attribution License (CCL), which permits unrestricted use, distribution, and reproduction in any medium, provided the original work is properly cited.

Dates: Received: 04 February 2018; Revised: 10 April: 2018; Accepted: 22 April 2018

Keywords: Concentrations, Hydrocarbons, Fish, Safety

Polycyclic aromatic hydrocarbons (PAHs) are a class of ubiquitous organic compounds consisting of two or more fused aromatic rings. They are mostly hydrophobic and are capable of bio-accumulating in animal and human tissues (Zheng et al., 2007). Polycyclic aromatic hydrocarbons (PAHs) are classified as persistent organic pollutants commonly occurring in the environment and are considered to be one of the most difficult organic contaminants to treat (Edwards, 1983; Cerniglia, 1992; Weissenfels et al., 1992; Zheng et al., 2007). Due to their toxic, mutagenic and carcinogenic properties, they pose a significant environmental risk to public health (Chen and Liao, 2006). Sixteen (16) PAHs have been identified as priority pollutants by both the US Environment Protection Agency (USEPA) and the European Union (USEPA, 1977; European Union, Commission Recommendation, 2005).Generally, the presence of PAHs in the environment has increased over the last 100 years; however, global concentrations may have stabilized due to recent air and water quality regulations (Fernandez et al., 2000). PAHs concentrations in the environment are often closely related to local and regional sources, although remote areas can be sites of PAHs deposition through atmospheric processes and long range transport.
Ologe Lagoon and Badagry Creek are very important water bodies in Nigeria. Also, Chrysichthys nigrodigitatus and Macrobrachium macrobrachion are important components of the diet of the people of Lagos and its environs because they are available all year round. Therefore, the main aim of this study was to assess the level of polyaromatic hydrocarbons and total hydrocarbons in the water, sediment and fish species from Ologe Lagoon and Badagry Creek with regards to human health.

\section{MATERIALS AND METHODS}

Study Area: Badagry Creek and Ologe Lagoon are part of the continuous system of Lagoon and creeks along the coast of Nigeria. Badagry creek, the larger of the two sampling water bodies lies within longitude $2^{\circ} 42^{\prime} \mathrm{E}$ and $3^{\circ} 42^{\prime} \mathrm{E}$ and stretches between latitude $6^{\circ} 22^{\prime} \mathrm{N}$ and $6^{\circ} 42^{\prime} \mathrm{N}$, sharing boundary with Republic of Benin., River Yewa, Bawa and Doforo creeks also empties into it. It is about $60 \mathrm{~km}$ long and $3 \mathrm{~km}$ wide. Its depth ranges between 1-3m. Ologe Lagoon on the other hand is situated adjacent to Badagry creek between latitude $6^{0} 26^{\prime} \mathrm{N}$ and longitude $3001^{\prime} \mathrm{E}$ to $3^{0} 07^{\prime} \mathrm{E}$. It has a surface area of $9-42 \mathrm{~km}^{2}$ and is the smallest of the Lagoons in south western Nigeria. It receives water from Rivers Owo, Ore and Opomu, and waste waters 
from Agbara industrial and residential area.

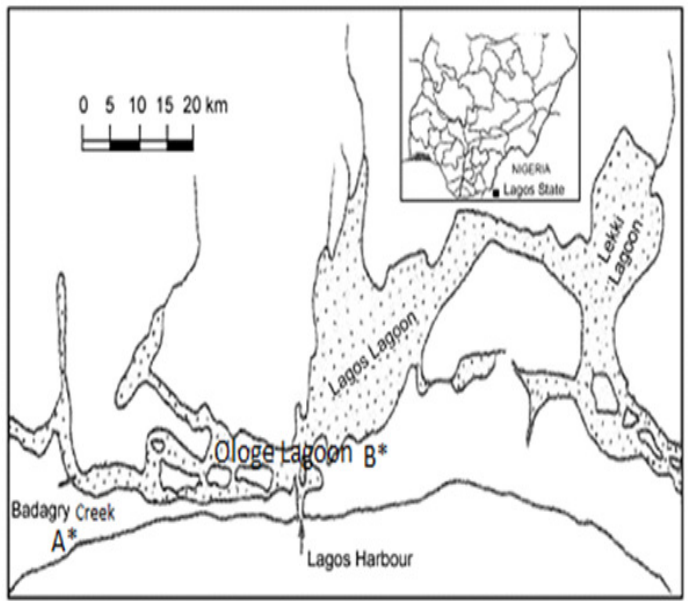

Fig 1: Map of Badagry Creek ( $\left.\mathrm{A}^{*}\right)$ and Ologe Lagoon (B*) in Lagos State, Nigeria

Samples Collection:Samples of water, sediments, fish and shell fish were collected from two different sampling points at Badagry Creek and Ologe Lagoon between August and October 2016, and subsequently treated following the methods of the American Public Health Association (APHA, 2005).

Extraction and fractionation of PAHs in Water Samples: $250 \mathrm{ml}$ each of the water samples was transferred into a separating funnel. The $\mathrm{pH}$ was adjusted to $<\mathrm{pH} 2$. The solution was then extracted twice with $15 \mathrm{ml}$ methylene chloride. The extract was dried with $5 \mathrm{~g}$ anhydrous sodium sulfate and concentrated to $1 \mathrm{ml}$ in rotary evaporator. $50 \mathrm{ml}$ of hexane was added and the sample extracted again down to $1 \mathrm{ml}$. The concentrate was fractioned, first eluted with $10 \mathrm{ml}$ hexane, and collected as aliphatic fraction, followed by elution with $15 \mathrm{ml}$ methylene chloride, and collected as aromatic fraction. Both fractions were concentrated to $1 \mathrm{ml}$ and stored capped in $\mathrm{GC}$ vials.

Extraction and fractionation of Sediment Samples: $10 \mathrm{~g}$ of the sediment sample was blended with $10 \mathrm{~g}$ of anhydrous sodium sulfate. The mixture was placed in an extraction thimble and refluxed for 4 hours with $50 \mathrm{ml}$ methylene chloride. Thereafter the solution was cooled, dried with $5 \mathrm{~g}$ anhydrous sodium sulfate, and concentrated to $1 \mathrm{ml}$ in a rotary evaporator. The concentrate was fractionated over silica gel column, first eluted with $10 \mathrm{ml}$ hexane and collected as aliphatic fraction, and then with $15 \mathrm{ml}$ methylene chloride, and collected as aromatic fraction.

Extraction and fractionation of Fish Samples: The fish sample was homogenized with a blender. A $2 \mathrm{~g}$ portion of the homogenate saponified with $200 \mathrm{ml}$
methanol/KOH(12\% KOH in $95 \%$ methanol) solution in an ultrasonic bath at $60{ }^{\circ} \mathrm{C}$, for $30 \mathrm{~min}$. The sample was cooled and filtered through glass cool into separatory funnel. The filtrate was extracted twice with $100 \mathrm{ml}$ hexane. The extract was washed with methanol/water (4:1) mixture, and then concentrated to $1 \mathrm{ml}$ with a rotary evaporator. The concentrate was fractionated through a silica gel column, first eluted with $10 \mathrm{ml}$ hexane to collect the aliphatic hydrocarbon fraction, and then with $15 \mathrm{ml}$ methylene chloride to collect the aromatic hydrocarbon fraction. Both fractions were concentrated to $1 \mathrm{ml}$ and stored capped in $\mathrm{GC}$ vials.

Determination of PAHs in the Solid Samples: $5 \mathrm{~g}$ of the sample was weighed into an extraction bottle and $20 \mathrm{ml}$ of dichloromethane was added and sonicated in an ultrasonic sonicator for $2 \mathrm{hrs}$. The extract was concentrated to $20 \mathrm{~cm}^{3}$ in a rotary evaporator. $20 \mathrm{ml}$ of $0.5 \mathrm{KOH}$ in $100 \mathrm{ml}$ of methanol was added and the mixture was refluxed for $1 \mathrm{hr}$ in a water bath at $60^{\circ} \mathrm{C}$. $20 \mathrm{~cm}^{3}$ deionized water was added and extracted with hexane $\left(20 \mathrm{~cm}^{3}\right)$. The extract was dried over anhydrous sodium sulphate and the extract was concentrated at $60^{\circ} \mathrm{C}$ in a rotary evaporator to $20 \mathrm{~cm}^{3}$. The extract was passed through silica gel column (DB 5 MS $(30 \mathrm{~m} \mathrm{x}$ $0.25 \mathrm{~mm} \times 0.5 \mu \mathrm{m})$ which had been pre-conditioned with hexane. The extract was eluted with $20 \mathrm{~cm}^{3}$ of hexane for aliphatic fractions. To some column, $20 \mathrm{~cm}^{3}$ dichloromethane was added for the elution of PAHs and the eluent was concentrated to $1 \mathrm{~cm}^{3}$ and solvent exchanged with $1 \mathrm{~cm}^{3}$ of actonitrile. $1 \mu \mathrm{L}$ of the extract was injected into a pre-programmed GC vials (HP 6890A). The concentration of the PAHs was calculated from the peak area of the calibration standards. $1 \mu \mathrm{L}$ of each of the fractions was injected into the GC, set-up for the quantification of PAHs and the petroleum hydrocarbons (WHO, 2003; APHA, 2005).

GC Operating Conditions for PAHs: Initial oven temp- $40^{\circ} \mathrm{C}$; Initial hold time- $2 \mathrm{~min}$; Ramp $-12^{\circ} \mathrm{C} / \mathrm{min}$ 40 to $300^{\circ} \mathrm{C}$ at $12^{\circ} \mathrm{C} / \mathrm{min}$ to $300^{\circ} \mathrm{C}$ for $10 \mathrm{~min}$; Final oven temp- $300^{\circ} \mathrm{C}$; Detector temp- FID $350^{\circ} \mathrm{C}$; Injector temp- $350^{\circ} \mathrm{C}$; Carrier gas- Hydrogen, 4 $\mathrm{ml} / \mathrm{min}$; constant flow; Injection volume- $1 \mu \mathrm{L}$, splitless, (hold $2 \mathrm{~min}$ )

Determination of THC: $3.0 \mathrm{~g}$ wet weight of each of the fish samples were homogenized in a mortar to paste using a pestle. The homogenized fish samples were freeze-dried for $48 \mathrm{hr}$. The samples were then extracted in a soxhlet apparatus for $8 \mathrm{hr}$ using a mixture of $\mathrm{n}$ hexane and dichloromethane according to WHO (2003). The total hydrocarbons in the extract were determined using UV spectrophotometer model DREL 
3000 at a wavelength of $450 \mathrm{~nm}$ against blank of nhexane.Total hydrocarbon content was determined by acidifying samples with concentrated sulphuric acid, and then extracting thrice with $25 \mathrm{ml}$ diethyl ether. The ethereal extract is evaporated and the residue cooled, and weighed. The THC is calculated as:THC $(\mathrm{mg} / \mathrm{kg})$ $=($ weight of residue $(\mathrm{mg}) \mathrm{x} 1000) /$ sample weight taken $(\mathrm{g})$

GC Set-up Conditions for THC: GC: HP 6890A, Column: DB $5 \mathrm{MS}(30 \mathrm{~m} \times 0.5 \mathrm{~mm} \times 0.15 \mu \mathrm{m})$, Oven: $60^{\circ} \mathrm{C}$ (hold $2 \mathrm{~min}$ ), 60 to $300^{\circ} \mathrm{C}$ at $12^{\circ} \mathrm{C} / \mathrm{min}$ to $300^{\circ} \mathrm{C}$ for $10 \mathrm{~min}$, Detector: FID $250^{\circ} \mathrm{C}$, Carrier Gas: Helium, $48.5 \mathrm{cml} / \mathrm{s}$; Make-up: nitrogen at $30 \mathrm{ml} / \mathrm{min}$, Injector: $350^{\circ} \mathrm{C}$, Injection volume: $1 \mu \mathrm{L}$, splitless,

GC Calibration Standards: THC Mix 1 (2000 mg/L) Diesel Fuel Standard $\left(\mathrm{C}_{10}-\mathrm{C}_{28}\right)$; EPA method $610 \mathrm{PAH}$ standard mix, Calibrate the GC using working standards (5-100 mg/L). Run samples and quantitate the components.

\section{RESULTS AND DISCUSSION}

The summary of the concentrations of various PAHs detected in water, sediment, $C$. nigrodigitatus and $M$. macrobrachion from Badagry Creek and Ologe Lagoon are shown in Table 1.

The same concentrations $(0.000 \pm 0.000 \mathrm{mg} / \mathrm{l})$ of naphthalene, acenaphthene, fluoranthene, Pyrene, chrysene, benzo (a) pyrene, rhenanthrene and acenaphthylene respectively were obtained in water samples from both Badagry Creek and Ologe Lagoon. On the other hand, concentrations of anthracene in surface water from Badagry creek and Ologe Lagoon are $0.000 \pm 0.000 \mathrm{mg} / \mathrm{l}$ and $0.001 \pm 0.001 \mathrm{mg} / \mathrm{l}$ respectively. The concentration of fluorine in the surface water at Badagry creek was $0.001 \pm 0.001 \mathrm{mg} / 1$ and $0.005 \pm 0.003 \mathrm{mg} / \mathrm{l}$ from Ologe Lagoon. Benzo (a) anthracene concentration in surface water at Badagry creek was $0.00 \pm 0.00 \mathrm{mg} / \mathrm{l}$ while $0.015 \pm 0.007 \mathrm{mg} / \mathrm{l}$ was obtained from Ologe Lagoon.

Naphthalene values $(0.007 \pm 0.001 \mu \mathrm{g} / \mathrm{g})$ and $(0.007 \pm$ $0.005 \mu \mathrm{g} / \mathrm{g}$ ) were recorded in sediment from Badagry creek and Ologe Lagoon respectively. The concentration of acenaphthene in bottom sediment from Badagry creek was $0.002 \pm 0.001 \mu \mathrm{g} / \mathrm{g}$ while $0.002 \pm 0.002 \mu \mathrm{g} / \mathrm{g}$ was obtained in Ologe Lagoon. The concentration $(0.003 \pm 0.002 \mu \mathrm{g} / \mathrm{g})$ of anthracene was recorded in bottom sediments from Badagry creek while at Ologe Lagoon, $0.005 \pm 0.004 \mu \mathrm{g} / \mathrm{g}$ was detected in the sediment. The concentration of fluorine obtained in the sediments was $0.008 \pm 0.009 \mu \mathrm{g} / \mathrm{g}$ and
$0.002 \pm 0.001 \mu \mathrm{g} / \mathrm{g}$ from Badagry creek and Ologe Lagoon respectively. The concentration of fluoranthene in bottom sediments was higher in Badagry creek $(0.006 \pm 0.008 \mu \mathrm{g} / \mathrm{g})$ than in Ologe Lagoon $(0.000 \pm 0.000 \mu \mathrm{g} / \mathrm{g})$. The concentration of benzo (a) anthracene in bottom sediments was lower in Badagry creek $(0.001 \pm 0.001 \mu \mathrm{g} / \mathrm{g})$ when compare to Ologe lagoon $(0.005 \pm 0.006 \mu \mathrm{g} / \mathrm{g})$. The concentration of pyrene in bottom sediments from both Badagry creek and Ologe lagoon respectively are $(0.004 \pm 0.004 \mu \mathrm{g} / \mathrm{g})$ and $(0.004 \pm 0.003 \mu \mathrm{g} / \mathrm{g})$. The concentration of chrysene in bottom sediments was lower in Badagry creek $(0.011 \pm 0.03 \mu \mathrm{g} / \mathrm{g})$ than in Ologe Lagoon $(0.024 \pm 0.010 \mu \mathrm{g} / \mathrm{g})$. The concentration of benzo (a) pyrene $(0.000 \pm 0.000 \mu \mathrm{g} / \mathrm{g})$ were obtained in bottom sediments from both Badagry creek and Ologe Lagoon. The concentration of rhenanthrene in bottom sediments was lower in Badagry creek $(0.002 \pm 0.002 \mu \mathrm{g} / \mathrm{g})$ in comparison with that in Ologe lagoon $(0.005 \pm 0.007 \mu \mathrm{g} / \mathrm{g})$. The concentration of acenaphthylene in bottom sediments was also lower in Badagry creek $(0.000 \pm 0.000 \mu \mathrm{g} / \mathrm{g})$ than in Ologe Lagoon $(0.001 \pm 0.001 \mu \mathrm{g} / \mathrm{g})$.

Similar concentrations $\quad(0.000 \quad \pm 0.000 \mu \mathrm{g} / \mathrm{g})$ of naphthalene were obtained in $C$. nigrodigitatus and $M$. macrobrachion at Ologe Lagoon and Badagry Creek. The concentration of acenaphthene( $0.000 \pm 0.000$ $\mu \mathrm{g} / \mathrm{g}$ ) were recorded in $C$. nigrodigitatus and $M$. macrobrachion from Badagry creek, while 0.001士 $0.000 \mu \mathrm{g} / \mathrm{g}$ and $0.002 \pm 0.003 \mu \mathrm{g} / \mathrm{g}$ concentration of acenaphthene were recorded respectively in $C$. nigrodigitatus and $M$. macrobrachion at Ologe Lagoon. The same concentration of $0.000 \pm 0.000 \mu \mathrm{g} / \mathrm{g}$ of fluorine was obtained in $C$. nigrodigitatus and $M$. macrobrachion at both Badagry creek and Ologe Lagoon. The concentration of anthracene in fin fishes was lower in Badagry creek $(0.000 \pm 0.000 \mu \mathrm{g} / \mathrm{g})$ than in Ologe Lagoon $(0.003 \pm 0.004 \mu \mathrm{g} / \mathrm{g})$. The concentration of anthracene in shell fishes was lower in Badagry creek $(0.00 \pm 0.00 \mu \mathrm{g} / \mathrm{g})$ than in Ologe Lagoon $(0.001 \pm 0.001 \mu \mathrm{g} / \mathrm{g})$. The concentrations of fluoranthene in fin fishes were low both in Badagry creek $(0.00 \pm 0.00 \mu \mathrm{g} / \mathrm{g})$ and Ologe Lagoon $(0.00 \pm$ $0.00 \mu \mathrm{g} / \mathrm{g})$. The concentration of fluoranthene in shell fishes was low both in Badagry creek (0.00 \pm $0.00 \mu \mathrm{g} / \mathrm{g})$ and Ologe Lagoon $(0.00 \pm 0.00 \mu \mathrm{g} / \mathrm{g})$. The concentration of benzo (a) anthracene in fin fishes was lower in Badagry creek $(0.00 \pm 0.00 \mu \mathrm{g} / \mathrm{g})$ than those in Ologe Lagoon $(0.002 \pm 0.003 \mu \mathrm{g} / \mathrm{g})$. The concentration of benzo (a) anthracene in shell fish was lower in Badagry creek $(0.00 \pm 0.00 \mu \mathrm{g} / \mathrm{g})$ as compared to Ologe Lagoon $(0.002 \pm 0.003 \mu \mathrm{g} / \mathrm{g})$. 
Table 1: Mean concentration \pm Standard deviation of PAHs and THC in surface water, bottom sediment, C. nigrodigitatus and $M$. macrobrachion from Badagry creek and Ologe Lagoon.

\begin{tabular}{|c|c|c|c|c|c|c|c|c|}
\hline & \multicolumn{4}{|c|}{ Badagry creekTest } & \multicolumn{4}{|c|}{ Ologe Lagoon Test } \\
\hline & Surface water & Sediment & $\begin{array}{l}\text { C.nigrodigi } \\
\text { tatus }\end{array}$ & $\begin{array}{l}\text { M.macrobr } \\
\text { achion }\end{array}$ & $\begin{array}{l}\text { Surface } \\
\text { Water }\end{array}$ & $\begin{array}{l}\text { Sedimen } \\
\mathrm{t}\end{array}$ & $\begin{array}{l}\text { C.nigrodi } \\
\text { gitatus }\end{array}$ & $\begin{array}{l}\text { M.macrob } \\
\text { rachion }\end{array}$ \\
\hline Naphthalene $(\mu \mathrm{g} / \mathrm{g})$ & $0.000 \pm 0.000^{\mathrm{a}}$ & $\begin{array}{l}0.007 \pm \\
0.001^{\mathrm{a}}\end{array}$ & $\begin{array}{l}0.000 \pm \\
0.000^{\mathrm{a}}\end{array}$ & $\begin{array}{l}0.000 \pm \\
0.000^{\mathrm{a}}\end{array}$ & $\begin{array}{l}0.000 \pm \\
0.000^{\mathrm{a}}\end{array}$ & $\begin{array}{l}0.007 \pm \\
0.005^{\mathrm{a}}\end{array}$ & $\begin{array}{l}0.000 \pm \\
0.000^{\mathrm{a}}\end{array}$ & $\begin{array}{l}0.000 \pm \\
0.000^{\mathrm{a}}\end{array}$ \\
\hline Acenapthene $(\mu \mathrm{g} / \mathrm{g})$ & $\begin{array}{l}0.000 \pm \\
0.000^{\mathrm{a}}\end{array}$ & $\begin{array}{l}0.002 \pm \\
0.001^{\mathrm{a}}\end{array}$ & $\begin{array}{l}0.000 \pm \\
0.000^{\mathrm{a}}\end{array}$ & $\begin{array}{l}0.000 \pm \\
0.000^{\mathrm{a}}\end{array}$ & $\begin{array}{l}0.000 \pm \\
0.000^{\mathrm{a}}\end{array}$ & $\begin{array}{l}0.002 \pm \\
0.002^{\mathrm{a}}\end{array}$ & $\begin{array}{l}0.001 \pm \\
0.001^{\mathrm{a}}\end{array}$ & $\begin{array}{l}0.002 \pm \\
0.001^{\mathrm{a}}\end{array}$ \\
\hline Fluorine $(\mu \mathrm{g} / \mathrm{g})$ & $\begin{array}{l}0.001 \pm \\
0.001^{\mathrm{a}}\end{array}$ & $\begin{array}{l}0.008 \pm \\
0.009^{\mathrm{a}}\end{array}$ & $\begin{array}{l}0.000 \pm \\
0.000^{\mathrm{a}}\end{array}$ & $\begin{array}{l}0.000 \pm \\
0.000^{\mathrm{a}}\end{array}$ & $\begin{array}{l}0.005 \pm \\
0.003^{\mathrm{a}}\end{array}$ & $\begin{array}{l}0.002 \pm \\
0.001^{\mathrm{a}}\end{array}$ & $\begin{array}{l}0.000 \pm \\
0.000^{\mathrm{a}}\end{array}$ & $\begin{array}{l}0.000 \pm \\
0.000^{\mathrm{a}}\end{array}$ \\
\hline Anthracene $(\mu \mathrm{g} / \mathrm{g})$ & $\begin{array}{l}0.000 \pm \\
0.000^{\mathrm{a}}\end{array}$ & $\begin{array}{l}0.003 \pm \\
0.002^{\mathrm{a}}\end{array}$ & $\begin{array}{l}0.000 \pm \\
0.000^{\mathrm{a}}\end{array}$ & $\begin{array}{l}0.000 \pm \\
0.000^{\mathrm{a}}\end{array}$ & $\begin{array}{l}0.001 \pm \\
0.001^{\mathrm{a}}\end{array}$ & $\begin{array}{l}0.005 \pm \\
0.004^{\mathrm{a}}\end{array}$ & $\begin{array}{l}0.003 \pm \\
0.004^{\mathrm{a}}\end{array}$ & $\begin{array}{l}0.001 \pm \\
0.001^{\mathrm{a}}\end{array}$ \\
\hline Fluoranthene $(\mu \mathrm{g} / \mathrm{g})$ & $\begin{array}{l}0.000 \pm \\
0.000^{\mathrm{a}}\end{array}$ & $\begin{array}{l}0.008 \pm \\
0.006^{\mathrm{a}}\end{array}$ & $\begin{array}{l}0.000 \pm \\
0.000^{\mathrm{a}}\end{array}$ & $\begin{array}{l}0.000 \pm \\
0.000^{\mathrm{a}}\end{array}$ & $\begin{array}{l}0.000 \pm \\
0.000^{\mathrm{a}}\end{array}$ & $\begin{array}{l}0.000 \pm \\
0.000^{\mathrm{a}}\end{array}$ & $\begin{array}{l}0.000 \pm \\
0.000^{\mathrm{a}}\end{array}$ & $\begin{array}{l}0.000 \pm \\
0.000^{\mathrm{a}}\end{array}$ \\
\hline Benzo(a)anthracene $(\mu \mathrm{g} / \mathrm{g})$ & $\begin{array}{l}0.000 \pm \\
0.000^{\mathrm{a}}\end{array}$ & $\begin{array}{l}0.001 \pm \\
0.001^{\mathrm{a}}\end{array}$ & $\begin{array}{l}0.000 \pm \\
0.000^{\mathrm{a}}\end{array}$ & $\begin{array}{l}0.000 \pm \\
0.000^{\mathrm{a}}\end{array}$ & $\begin{array}{l}0.015 \pm \\
0.007^{\mathrm{a}}\end{array}$ & $\begin{array}{l}0.006 \pm \\
0.005^{\mathrm{a}}\end{array}$ & $\begin{array}{l}0.003 \pm \\
0.002^{\mathrm{a}}\end{array}$ & $\begin{array}{l}0.003 \pm \\
0.002^{\mathrm{a}}\end{array}$ \\
\hline Pyrene $(\mu \mathrm{g} / \mathrm{g})$ & $\begin{array}{l}0.000 \pm \\
0.000^{\mathrm{a}}\end{array}$ & $\begin{array}{l}0.004 \pm \\
0.004^{\mathrm{a}}\end{array}$ & $\begin{array}{l}0.001 \pm \\
0.001^{\mathrm{a}}\end{array}$ & $\begin{array}{l}0.003 \pm \\
0.002^{\mathrm{a}}\end{array}$ & $\begin{array}{l}0.000 \pm \\
0.000^{\mathrm{a}}\end{array}$ & $\begin{array}{l}0.004 \pm \\
0.003^{\mathrm{a}}\end{array}$ & $\begin{array}{l}0.001 \pm \\
0.001^{\mathrm{a}}\end{array}$ & $\begin{array}{l}0.001 \pm \\
0.000^{\mathrm{a}}\end{array}$ \\
\hline Chrysene $(\mu \mathrm{g} / \mathrm{g})$ & $\begin{array}{l}0.000 \pm \\
0.000^{\mathrm{a}}\end{array}$ & $\begin{array}{l}0.011 \pm \\
0.003^{\mathrm{a}}\end{array}$ & $\begin{array}{l}0.000 \pm \\
0.000^{\mathrm{a}}\end{array}$ & $\begin{array}{l}0.000 \pm \\
0.000^{\mathrm{a}}\end{array}$ & $\begin{array}{l}0.000 \pm \\
0.000^{\mathrm{a}}\end{array}$ & $\begin{array}{l}0.024 \pm \\
0.010^{\mathrm{a}}\end{array}$ & $\begin{array}{l}0.000 \pm \\
0.000^{\mathrm{a}}\end{array}$ & $\begin{array}{l}0.001 \pm \\
0.000^{\mathrm{a}}\end{array}$ \\
\hline Benzo(a)pyrene $(\mu \mathrm{g} / \mathrm{g})$ & $\begin{array}{l}0.000 \pm \\
0.000^{\mathrm{a}}\end{array}$ & $\begin{array}{l}0.000 \pm \\
0.000^{\mathrm{a}}\end{array}$ & $\begin{array}{l}0.000 \pm \\
0.000^{\mathrm{a}}\end{array}$ & $\begin{array}{l}0.000 \pm \\
0.000^{\mathrm{a}}\end{array}$ & $\begin{array}{l}0.000 \pm \\
0.000^{\mathrm{a}}\end{array}$ & $\begin{array}{l}0.000 \pm \\
0.000^{\mathrm{a}}\end{array}$ & $\begin{array}{l}0.000 \pm \\
0.000^{\mathrm{a}}\end{array}$ & $\begin{array}{l}0.000 \pm \\
0.000^{\mathrm{a}}\end{array}$ \\
\hline Rhenanthrene $(\mu \mathrm{g} / \mathrm{g})$ & $\begin{array}{l}0.000 \pm \\
0.000^{\mathrm{a}}\end{array}$ & $\begin{array}{l}0.002 \pm \\
0.001^{\mathrm{a}}\end{array}$ & $\begin{array}{l}0.000 \pm \\
0.000^{\mathrm{a}}\end{array}$ & $\begin{array}{l}0.000 \pm 0.0 \\
00^{\mathrm{a}}\end{array}$ & $\begin{array}{l}0.000 \pm \\
0.000^{\mathrm{a}}\end{array}$ & $\begin{array}{l}0.007 \pm \\
0.005^{\mathrm{a}}\end{array}$ & $\begin{array}{l}0.000 \pm \\
0.000^{\mathrm{a}}\end{array}$ & $\begin{array}{l}0.000 \pm \\
0.000^{\mathrm{a}}\end{array}$ \\
\hline Acenaphthylene $(\mu \mathrm{g} / \mathrm{g})$ & $\begin{array}{l}0.000 \pm \\
0.000^{\mathrm{a}}\end{array}$ & $\begin{array}{l}0.000 \pm \\
0.000^{\mathrm{a}}\end{array}$ & $\begin{array}{l}0.000 \pm \\
0.000^{\mathrm{a}}\end{array}$ & $\begin{array}{l}0.000 \pm \\
0.000^{\mathrm{a}}\end{array}$ & $\begin{array}{l}0.000 \pm \\
0.000^{\mathrm{a}}\end{array}$ & $\begin{array}{l}0.001 \pm \\
0.001^{\mathrm{a}}\end{array}$ & $\begin{array}{l}0.000 \pm \\
0.000^{\mathrm{a}}\end{array}$ & $\begin{array}{l}0.000 \pm \\
0.000^{\mathrm{a}}\end{array}$ \\
\hline $\begin{array}{l}\text { Total hydrocarbon } \\
\text { Content }(\mu \mathrm{g} / \mathrm{g})\end{array}$ & $\begin{array}{l}0.495 \pm \\
0.035^{\mathrm{a}}\end{array}$ & $\begin{array}{l}12.090 \pm \\
8.641^{\mathrm{b}}\end{array}$ & $\begin{array}{l}27.210 \pm \\
15.429^{\mathrm{bc}}\end{array}$ & $\begin{array}{l}219.565 \pm 1 \\
71.891^{\mathrm{c}}\end{array}$ & $\begin{array}{l}0.695 \pm \\
0.417^{\mathrm{a}}\end{array}$ & $\begin{array}{l}38.57 \pm 9 \\
249^{\mathrm{ab}}\end{array}$ & $\begin{array}{l}104.505 \pm \\
23.342^{\text {bd }}\end{array}$ & $\begin{array}{l}211.565 \pm 1 \\
27.923^{\text {cd }}\end{array}$ \\
\hline
\end{tabular}

However, the concentrations $(0.001 \pm 0.001 \mu \mathrm{g} / \mathrm{g})$ of pyrene were recorded in fin fish from both water bodies. The concentration of pyrene in shell fish was higher in Badagry creek $(0.002 \pm 0.003 \mu \mathrm{g} / \mathrm{g})$ than in Ologe Lagoon $(0.001 \pm 0.000 \mu \mathrm{g} / \mathrm{g})$. The concentration $(0.000 \pm 0.000 \mu \mathrm{g} / \mathrm{g})$ of chrysene in fin fish were recorded from both Badagry creek and Ologe Lagoon. The concentration of chrysene in shell fish was lower in Badagry creek $(0.000 \pm 0.000 \mu \mathrm{g} / \mathrm{g})$ and higher in Ologe lagoon $(0.001 \pm 0.000 \mu \mathrm{g} / \mathrm{g})$.

The concentration $(0.000 \pm 0.000 \mu \mathrm{g} / \mathrm{g})$ of benzo (a) pyrene were recorded in fin fish from both Badagry creek and Ologe Lagoon. Similarly, the concentration $(0.000 \pm 0.000 \mu \mathrm{g} / \mathrm{g})$ of benzo (a) pyrene in shell fish were recorded from both Badagry creek and Ologe Lagoon. Also, same concentration $(0.000 \pm$ $0.000 \mu \mathrm{g} / \mathrm{g}$ ) of rhenanthrene were recorded in fin fish from Badagry creek and Ologe Lagoon respectively. The concentration of rhenanthrene in shell fish at both stations was $0.000 \pm 0.000 \mu \mathrm{g} / \mathrm{g}$. The concentration of acenaphthylene in both fin fish and shell fish respectively was $0.000 \pm 0.000 \mu \mathrm{g} / \mathrm{g}$ at both water bodies. There were no significant $(\mathrm{p}<0.05)$ different in all the PAHs examined in the samples collected from the two stations.

The mean concentration of the total hydrocarbon content in water, sediment, $C$. nigrodigitatus and $M$. macrobrachion respectively recorded in Badagry Creek were $(0.495 \pm 0.035 \mathrm{mg} / \mathrm{l}, 12.090 \pm 8.641 \mu \mathrm{g} / \mathrm{g}$, $27.210 \pm 15.429 \mu \mathrm{g} / \mathrm{g}$ and $219.565 \pm 171.891 \mu \mathrm{g} / \mathrm{g})$ while $(0.695 \pm 0.417 \mathrm{mg} / \mathrm{l}, \quad 38.57 \pm 9.249 \quad \mu \mathrm{g} / \mathrm{g}$,
$104.505 \pm 23.342 \mu \mathrm{g} / \mathrm{g}$ and $211.565 \pm 127.923 \mu \mathrm{g} / \mathrm{g}$ ) were obtained in Ologe Lagoon respectively (Table1). The highest concentration of the total hydrocarbon content $(219.565 \pm 171.891 \mu \mathrm{g} / \mathrm{g})$ from Badagry Creek was recorded in M.macrobrachion while the least $(0.495 \pm 0.035 \mathrm{mg} / \mathrm{l})$ was obtained in the water sample .Similarly, the highest THC $(211.565 \pm 127.923 \mu \mathrm{g} / \mathrm{g})$ was recorded in M.macrobrachion at Ologe Lagoon while the water sample had the least THC value of $0.695 \pm 0.417 \mathrm{mg} / \mathrm{l}$. There were significant differences $(\mathrm{p}<0.05)$ in the mean value of THC in sediment, $C$. nigrodigitatus and M. macrobrachion across the two stations.

The concentrations of all the PAHs examined in water, sediment, C.nigrodigitatus and M. macrobrachion from Badagry Creek and Ologe Lagoon were below the WHO maximum permissible limit of $10 \mathrm{mg} / \mathrm{l}$ in water, $0.01 \mu \mathrm{g} / \mathrm{g}$ in sediment, $0.001 \mu \mathrm{g} / \mathrm{g}$ in fish and shell fish respectively. The PAHs values in this study were lower than PAHs reported by Al-Busaidi et al., (2013) in marine Clam, Liochoncha ornata collected from the Omani sea; in rivers and estuaries of Malaysia (Zakaria et al., 2002); Asuquo and Udoh (1999) in Ethmalosa fimbriata and C. nigrodigitatus from Nigerian rivers; and Kpobari et al., (2013) in two Tilapia queneesis and Liza falcipinis from Ogoni land in Nigeria. Similarly ,the PAHs detected in this study are lower than those reported in stock fishes (Gardus morhua and Molva molva) by Eze and Ogbuehi (2015);Ayejuiyo, et al., (2012) and Liang et al., (2011) .The significant differences recorded in THC of sediment, C. nigrodigitatus and M. macrobrachion 
from the two sites was similar to the findings of Ibigoni et al.,(2009).However, the THC recorded in this study were lower than total hydrocarbon levels reported in the surface waters, sediments and biota in an oil polluted mangrove wetland in the Niger Delta (Ibigoni et al.,2009).

The higher total hydrocarbon concentrations recorded in the stations that have no oil formations could imply input result from other sources like domestic wastes, discharge of sewage, drifts from polluted areas and other activities (Ahmed, 1983). The sediment loads of THC all through the sampling periods and sites were consistently higher than that of the surface water indicating that it was a better indicator of pollution in the Lagoon system even after the sources of pollution has been removed. The hydrocarbon content of fish is mainly associated with the level of organic matter in the environment (Kucuksezin et al., 2006). These levels of total hydrocarbons suggest that the fish species might have fed on high amounts of petroleum or organic matter containing waste material from the industries and runoff from the urban areas (Kucuksezin et al., 2006). High hydrocarbon content causes oxygen deterioration by reduction in gaseous diffusion through the surface film of oil with far reaching implications for the flora and fauna of the affected area (Osuji et al., 2004).

The results also showed that the total hydrocarbon concentrations in the fish species studied were lower than those detected in Mytilus edulis from North Sea (Viddowet al., 1982) and higher than that reported by Asuquo et al., (2001)for total hydrocarbon in Mytilus edulis and Ethmalosa fimbriata from Cross River. The result also revealed that the total hydrocarbon in the fish species studied were all above the WHO permissible limit of heavy metals for seafood of 0.002 $\mu \mathrm{g} / \mathrm{g}$ (WHO, 1985). The THC detected in the study was higher than those obtained in Sphyrena afra, Oreochromis niloticus and Elops lacerta from Calabar (Edem et al., 2008) It was also higher than those found in Macura reptantia, Penaeus notialis and Ocypoda africanus from Bight of Bonny, Niger Delta in Nigeria (Nsikak et al., 2007) and David-Oku et al., (2006) in M. vollenhovenii from south eastern Nigeria.

Conclusion: The study has shown that the polyaromatic hydrocarbons were below the risk level, which indicated no risk status from the consumption of the fish species studied. On the contrary, the fin and shell fishes studied from these water bodies are highly contaminated with THC. Therefore, persistent monitoring and strict adherence to responsible waste discharge should be upheld by all industries near these waters in order to avoid deleterious effect of the biodiversity in these water bodies as well as ensuring safety of the consumers.

\section{REFERENCES}

Ahmed, SM (1983). Oil pollution studies in the Nile River. Environ. Int. 9:107-111.

Al-Busaidi, M; Yesudhason, P; Alwaili, A; Al-Rahbi, W; Al-Harthy, K; Al-MAzrooei, N; Al-Habsi, S (2013). Accumulation of some potentially toxic metals and polycyclic aromatic hydrocarbons (PAHs) in marine Clam Liochoncha ornata collected from the Omani sea. Int. J. Fish.Aqua.5 (9): 238-247.

APHA, (2005). Standard Methods for the Examination of Water and Wastewater, 21st edition American Public Health Association. Washington DC, $1368 p$.

Asuquo, FE; Udoh G (1999). Pollution Patterns of Hydrocarbon, Copper $(\mathrm{Cu})$ and Iron $(\mathrm{Fe})$ in Ethmalosa fimbriata (Bowdich, 1852) and Chrysichthys nigrodigitatus(Lacepede, 1803) from Nigerian Rivers. Int. J. Trop. Environ. 2 (2):10-15.

Ayejuyo, OO; Obijoiofor, R; Osundiya, MO (2012). Levels of PAHs and Potentially Toxic metals in three species of fresh and smoked fish consumed in Lagos, Nigeria. J. Appl. Chem.5: 30-35.

Cerniglia, CE (1992). Biodegradation of polycyclic aromatic hydrocarbons. Biodegrad.3:351-358.

Chen, SC; Liao, CM (2006) Health risk assessment on human exposed to environmental polycyclic aromatic hydrocarbons pollution sources. Sci. Tol. Environ. 366:112-123.

David-Oku, E; Usang, EE; Akpan, ER (2006). Total hydrocarbons, trace metals and micro-elements in freshwater prawn, Macrobrachium vollenhovenii from south Eastern Nigeria. Afr. J. Environ. Poll. H. 5(2): 32-38.

Edem, CA; Akpan, SB; Dosumu, MI (2008). A Comparative Assessment of Heavy Metals and Total Hydrocarbon Accumulation in Sphyrena afra, Oreochromis niloticus and Elops lacerta from Anantigha Beach Market in calabarNigeria. Afr. J. Environ. Poll. H.6 (1): 61-64.

Edwards, NT (1983). Polycyclic aromatic hydrocarbons (PAH's) in the terrestrial environment - a review. J. Environ. Qua. 12: $427-441$. 
European Union, Commission Recommendation (2005) 2005/108/EC. Off. J. Europ. Comm. 34: 43.

Eze, SO; Ogbuehi, GI (2015).Assessment of heavy metals and polycyclic aromatic hydrocarbon concentration in some stockfish species sold in five major markets of Aba south, Abia state, Nigeria. Europ. J. Pur. Appl. Chem. 2 (1):1-7.

Fernandez, P; Vilanova, RM; Martinez, C; Appleby, P; Grimalt, JO (2000). The historical record of atmospheric pyrolytic pollution over Europe registered in the sedimentary $\mathrm{PAH}$ from remote mountain lakes. Environ. Sci. Technol. 34: 19061913.

Ibigoni, CH; Ugwemorubong UG; Horsfall, M(2009).Evaluation of Total Hydrocarbon Levels in some Aquatic Media in an Oil Polluted Mangrove Wetland in the Niger Delta. Appl. Ecol. Environ. Res. 7(2): 111-120.

Kpobari, WN; Mathew, OW; Eka, BE (2013). Assessment of Polycyclic Aromatic Hydrocarbons (PAHs) levels in two commercially important fish species from crude oil polluted waters of Ogoniland and their carcinogenic health risks. J. Environ. Ear. Sci. 3(8):128-137.

Kucuksezgin, FA; Kontas, O; Altay, E; Uluturhan, E; Davilmaz, (2006).Assessment of marine pollution in Izmir Bay; Nutrient heavy metal and total hydrocarbon concentrations. Environ. Int. 32: 4151.

Liang, T; Young, L; Wong, MH (2011). Distribution pattern of polycyclic aromatic hydrocarbons (PAHs) in the sediments and fish at Mai marshes nature Roseve", Hong Kong Wat. Res. 41:13011311.

Nsikak, UB; Essien, JP; Williams, AB; Ebong, GA (2007). Petroleum Hydrocarbons Accumulation Potential of Shellfishes from Littoral Waters of the Bight of Bonny, Niger Delta, Nigeria. Res. J. Environ. Sci. 1: 11-19.

Osuji, LC; Adesiyan SO; Obute, GC (2004): Post impact assessment of oil pollution in Agbada west plain of Niger Delta Nigeria: Field reconnaissance and total extractable hydrocarbon content. Chem. Biodiv. 1: 1569-1577.

USEPA (1977). Sampling and Analysis Procedures for Screening of Industrial Effluents for Priority Pollutants. Environment Monitoring and Support Laboratory, Cincinnati. Washington DC, USA.1240p

Viddow J; Bakke, T; Bayne, BL; Donkin, P; Livingstone, DR; Lowe, DM; Moore, MN; Evans, SV; Moore, SL (1982).Response of Mytilus edulis on exposure to the water accumulated fraction of North sea oil. Mar. Bio. 67 (1): 21-24.

Weissenfels, WD; Klewer, HJ; Langhoff, J (1992). Adsorption of polycyclic aromatic hydrocarbons (PAHs) by soil particles: influence on biodegradability and biotoxicity. Appl. Microbiol. Biotechnol. 36, 689-696.

World Health Organization (2003). Polynuclear aromatic hydrocarbons in Drinking-water. Background document for development of WHO Guidelines for Drinking-water Quality, World Health Organization., Geneva.

Zakaria, MP; Takada, H; Tsutsumi, S; Ohno, K; Yamada, J; Kouno, E(2002). Distribution of polycyclic aromatic hydrocarbons (PAHs) in rivers and estuaries in Malaysia: a widespread input of petrogenic PAHs. Environ. Sci. Technol. 36 (9): 1907-1918.

Zheng, XJ; Blais, JF; Mercier, G; Bergeron, M; Drogui, P (2007).PAH removal from spiked municipal wastewater sewage sludge using biological, chemical and electrochemical treatments. Chemos. 68: 1143-1152. 